\title{
ASSESSMENT OF THE INDOOR AIR QUALITY OF AKURE, NIGERIA
}

\author{
Francis Olawale Abulude ${ }^{1,2^{*}}$ Samuel Dare Fagbayide ${ }^{3}$, Akinyinka Akinnusotu ${ }^{4}$, Olatunde \\ Elubode Makinde ${ }^{5}$, and Jamok Elisha ${ }^{6}$ \\ ${ }^{1}$ Department of Chemistry, Federal University of Technology, Minna, Niger State, Nigeria \\ ${ }^{2}$ Science and Education Development Institute, Akure, Ondo State, Nigeria \\ ${ }^{3}$ Agricultural and Bio-Environmental Engineering Department, Federal Polytechnic Ilaro, Ogun \\ State, Nigeria \\ ${ }^{4}$ Science Laboratory Technology Department, Rufus Giwa Polytechnic, Owo, Ondo State, \\ Nigeria \\ ${ }^{5}$ Chemistry Advanced Research Center, Sheda Science and Technology Complex, Abuja \\ ${ }^{6}$ Centre for Biotechnology Research and Training, Ahmadu Bello University, Zaria, Nigeria \\ *Correspondence author: walefut@gmail.com
}

\begin{abstract}
Air quality has been a major concern throughout the world, Nigeria inclusive. The monitoring of air quality involves indoor and outdoor air quality. In this study, our concern was on indoor air quality. The aim of this study was to assess the air quality of residential homes (17), classrooms (3), hospitals (2), offices (5), Shops (2), and laboratories (5) in Akure, Nigeria in terms of formaldehyde (HCHO), total volatile organic compound (TVOC), Particulate matter $\left(\mathrm{PM}_{1.0}\right.$; $\mathrm{PM}_{2.5}$, and $\mathrm{PM}_{10}$ ). A Multifunction Air Detector was used for the assessment using the manufacturers' procedures and the locations were identified using a Mini GPS. The results revealed as follows: HCHO $\left(0.001-0.030 \mathrm{mg} / \mathrm{m}^{3}\right)$, TVOC $\left(0.003-362 \mathrm{mg} / \mathrm{m}^{3}\right), \mathrm{PM}_{1.0}(004-014$ $\left.\mu \mathrm{g} / \mathrm{m}^{3}\right), \mathrm{PM}_{2.5}\left(006-020 \mu \mathrm{g} / \mathrm{m}^{3}\right)$, and $\mathrm{PM}_{10}\left(006-022 \mu \mathrm{g} / \mathrm{m}^{3}\right)$. The results obtained were below the $24 \mathrm{~h}$ pollution recommended standards $\left(0.1 \mathrm{mg} / \mathrm{m}^{3}\right.$ - HCHO; TVOC; $\left.10-20 \mu / \mathrm{m}^{3} \mathrm{PM}\right)$ of EPA and WHO. Statistically, there were correlations within the pollutants and weather. The Indoor air quality (IAQ) depicted the areas as 'good,' and toxicity potential (TP) were below unity. Although the locations looked safe, it is recommended that constant monitoring of the indoors should be ensured and proper ventilation should be provided.
\end{abstract}

Keywords: Indoor, classrooms, residential rooms, air detector, PM, TVOC, EPA

\section{Introduction}

The concern over indoor air quality worldwide is on the increase due to its attendant problem caused mostly on children, pregnant women and the elderly. Common pollutants indoors are: volatile organic compounds (TVOC), formaldehyde ( $\mathrm{HCHO}$ ), fine particulate matter (PM), ozone $\left(\mathrm{O}_{3}\right)$, carbon monoxide $(\mathrm{CO}), \mathrm{CO}_{2}$, and aldehydes caused by indoor emission sources like furniture, paints, combustion appliances, low ventilation within, seasonal variations, meteorological factors, and many other environmental factors (Lee et al., 2018; Walgraeve et al., 2011).

Indoor air pollution is a serious health threat. Studies indicate that the concentrations of air pollutants are sometimes 2-5 times higher in indoor air than outdoor air while in a few cases, indoor air pollutants could be over 100 times higher than outdoors (U.S. Consumer Product Safety Commission (CPSC), 2012). People spend over 90\% of their time indoors, for this 
singular reason; there should be a concern for the assessment, monitoring, and reduction of indoor pollutants.

Indoor air quality (IAQ) and toxicity potential (TP) of pollutants are important in the considerations of air pollutants indoors. The two inform people about the quality of the rooms and potential dangers one might encounter if the pollutants exceed the recommended limits. According to Sonibare et al. (2005), TP is a quantitative toxic equivalency which to express the potential effect of a unit of chemical released into the environment. This is expressed as the ratio of measured ambient pollutants' concentrations to the statutory limit of ambient concentration.

Toxicity Potential $=\frac{\mathrm{Mp}}{\mathrm{Sp}}$

Mp - the measured pollutant concentration; Sp - the statutory limit set for such pollutant using FMEnv Standard and ASHRAE Standard. TP is useful in determining the harmful effects of the emissions from the source pollutants within the indoors on human health (Ayodele et al., 2016). IAQ refers to the extent to which human requirements are met indoors. The requirements of the people are pleasant and fresh air, which has no negative impact on their health (Fanger, 2006).

Several studies on indoor air quality have been published for example, Wang et al. (2008); Petry et al. (2014), Chen et al. (2016); Shi et al. (2016); Me`ciarová et al. (2017); Lee et al. (2018) many of the interests were on PM, TVOC, formaldehyde, $\mathrm{O}_{3}, \mathrm{CO}, \mathrm{CO}_{2}$, and other aldehydes. Many of their observations were elevated levels of the parameters over the recommended standards. Different source apportionment (Li et al., 2014; Ma et al., 2016), methodologies (Chen et al. (2016); Shi et al. (2016); Me`ciarová et al. (2017); Lee et al. (2018), and instruments (Jiao et al., 2015; Van den Bossche et al., 2016; Zikova et al., 2017; Lee et al., 2018) have been used to determine and identify air pollution parameters. In Nigeria, many studies have not been done on indoor air pollution in Nigeria, but few literates obtained were done in Enugu (Ezezue and Diogu, 2017), Warri (Akpofure, 2015), Ile - Ife (Afolabi et al., 2016), Ido Ekiti (Ayodele et al., 2016), No report has been found for indoor pollution from Akure. On this note, the aim of the study was to assess the $\mathrm{HCHO}, \mathrm{TVOC}, \mathrm{PM}_{1}, \mathrm{PM}_{2.5}$, and $\mathrm{PM}_{10}$ in Akure, the relationship between the weather and the pollutants would be determined, the results would be subjected to multivariate analysis, and the potential toxicity of the pollutants would also determined. The results of the study will be an addition to indoor pollution knowledge in Akure, Nigeria, and beyond. 


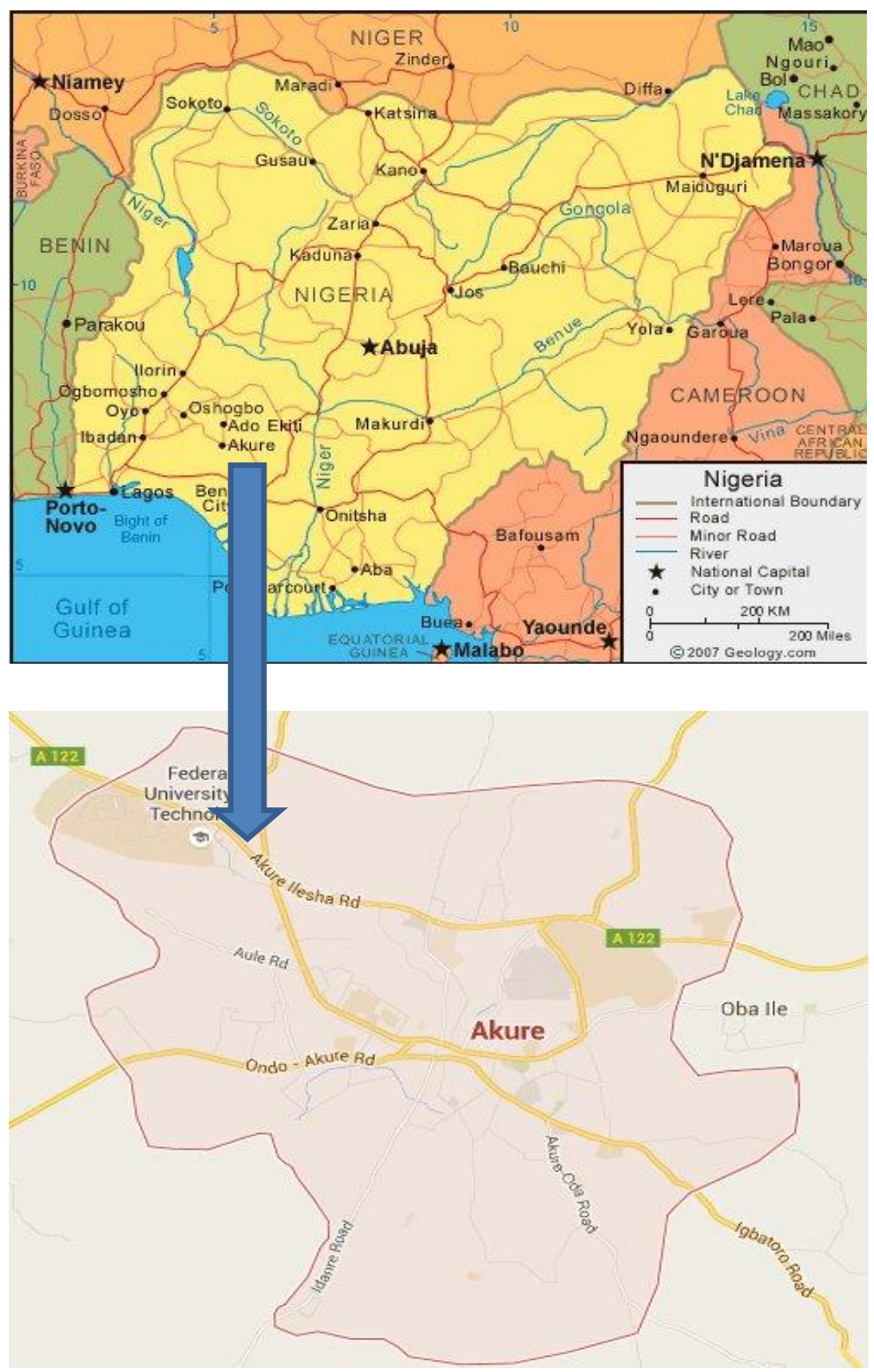

Fig 1. Akure, Ondo State, Nigeria

\section{Materials and Methods}

\subsection{Study Area}

Akure is the capital city of Ondo State (Fig 1). It is one of the beautiful cities in Nigeria. It is still undergoing rapid industrialization and urbanization over the past decades (Abulude et al., 2018a). Like other cities in other countries of the world, the air quality in Akure has been subjected to high pressure due to the vast economic development and an increase in housing. In different megacities in Nigeria, serious particle pollution, especially $\mathrm{PM}_{2.5}$ and $\mathrm{PM}_{10}$ pollution have been identified in Akure in recent years (Abulude et al., 2018b). 
Table 1. The Description of the locations

\begin{tabular}{|c|c|c|c|c|}
\hline $\mathrm{S} / \mathrm{N}$ & \multicolumn{2}{|c|}{ Locations } & Description & Date of Sampling \\
\hline 1. & $7^{\circ} 16^{\prime} 09.36^{\prime \prime} \mathrm{N}$ & $5^{\circ} 15^{\prime} 14.20^{\prime \prime} \mathrm{E}$ & Residential & $10 / 10 / 2018$ \\
\hline 2. & $7^{\circ} 16^{\prime} 09.10^{\prime \prime} \mathrm{N}$ & $5^{\circ} 15^{\prime} 13.24$ '’E & Residential & $10 / 10 / 2018$ \\
\hline 3. & $7^{\circ} 16^{\prime} 07.12^{\prime \prime} \mathrm{N}$ & $5^{\circ} 15^{\prime} 13.50^{\prime \prime} \mathrm{E}$ & Residential & $10 / 10 / 2018$ \\
\hline 4. & $7^{\circ} 16^{\prime} 06.20^{\prime \prime} \mathrm{N}$ & $5^{\circ} 15^{\prime} 12.72$ '”E & Residential & $10 / 10 / 2018$ \\
\hline 5. & $7^{\circ} 16^{\prime} 06.81^{\prime \prime} \mathrm{N}$ & $5^{\circ} 15^{\prime} 11.76^{\prime \prime} \mathrm{E}$ & Residential & $10 / 10 / 2018$ \\
\hline 6. & $7^{\circ} 16^{\prime} 03.29^{\prime \prime} \mathrm{N}$ & $5^{\circ} 15^{\prime} 13.40^{\prime \prime} \mathrm{E}$ & Residential & $11 / 10 / 2018$ \\
\hline 7. & $7^{\circ} 16^{\prime} 03.27^{\prime \prime} \mathrm{N}$ & $5^{\circ} 15^{\prime} 14.52^{\prime \prime} \mathrm{E}$ & Residential & $11 / 10 / 2018$ \\
\hline 8. & $7^{\circ} 15^{\prime} 59.98^{\prime \prime} \mathrm{N}$ & $5^{\circ} 15^{\prime} 10.27^{\prime \prime} \mathrm{E}$ & Residential & $11 / 10 / 2018$ \\
\hline 9. & $7^{\circ} 16^{\prime} 03.22^{\prime \prime} \mathrm{N}$ & $5^{\circ} 15^{\prime} 11.52^{\prime \prime} \mathrm{E}$ & Residential & $11 / 10 / 2018$ \\
\hline 10. & $7^{\circ} 16^{\prime} 04.78^{\prime \prime} \mathrm{N}$ & $5^{\circ} 15^{\prime} 14.34$ '’ $\mathrm{E}$ & Residential & $12 / 10 / 2018$ \\
\hline 11. & $7^{\circ} 16^{\prime} 07.09$ '” N & $5^{\circ} 15^{\prime} 14.98^{\prime \prime} \mathrm{E}$ & Residential & $12 / 10 / 2018$ \\
\hline 12. & $7^{\circ} 15^{\prime} 53.58^{\prime \prime} \mathrm{N}$ & $5^{\circ} 15^{\prime} 21.20^{\prime \prime} \mathrm{E}$ & Residential & $12 / 10 / 2018$ \\
\hline 13. & $7^{\circ} 15^{\prime} 48.84^{\prime \prime} \mathrm{N}$ & $5^{\circ} 14^{\prime} 21.82^{\prime \prime} \mathrm{E}$ & Residential & $12 / 10 / 2018$ \\
\hline 14. & $7^{\circ} 15^{\prime} 49.24^{\prime \prime} \mathrm{N}$ & $5^{\circ} 14 ' 22.42^{\prime \prime} \mathrm{E}$ & Residential & $13 / 10 / 2018$ \\
\hline 15. & $7^{\circ} 15^{\prime} 50.07^{\prime \prime} \mathrm{N}$ & $5^{\circ} 14^{\prime} 22.83^{\prime \prime} \mathrm{E}$ & Residential & $13 / 10 / 2018$ \\
\hline 16. & $7^{\circ} 16^{\prime} 06.02^{\prime \prime} \mathrm{N}$ & $5^{\circ} 15^{\prime} 13.68^{\prime \prime} \mathrm{E}$ & Residential & $13 / 10 / 2018$ \\
\hline 17. & $7^{\circ} 16^{\prime} 08.21^{\prime \prime} \mathrm{N}$ & $5^{\circ} 15^{\prime} 26.03^{\prime \prime} \mathrm{E}$ & Residential & $13 / 10 / 2018$ \\
\hline 18. & $7^{\circ} 15^{\prime} 49.33^{\prime \prime} \mathrm{N}$ & $5^{\circ} 14^{\prime} 24.28^{\prime \prime} \mathrm{E}$ & Shop & $13 / 10 / 2018$ \\
\hline 19. & $7^{\circ} 16^{\prime} 10.14^{\prime \prime} \mathrm{N}$ & $5^{\circ} 13$ '38.54'’ $\mathrm{E}$ & Laboratory & $14 / 10 / 2018$ \\
\hline 20. & $7^{\circ} 16^{\prime} 10.00^{\prime \prime} \mathrm{N}$ & $5^{\circ} 13 ' 38.30^{\prime \prime} \mathrm{E}$ & Laboratory & $14 / 10 / 2018$ \\
\hline 21. & $7^{\circ} 16^{\prime} 09.999^{\prime \prime} \mathrm{N}$ & $5^{\circ} 13^{\prime} 38.29^{\prime \prime} \mathrm{E}$ & Laboratory & $14 / 10 / 2018$ \\
\hline 22. & $7^{\circ} 16^{\prime} 10.01{ }^{\prime \prime} \mathrm{N}$ & $5^{\circ} 13^{\prime} 38.25^{\prime \prime} \mathrm{E}$ & Laboratory & $14 / 10 / 2018$ \\
\hline 23. & $7^{\circ} 15^{\prime} 46.61^{\prime \prime} \mathrm{N}$ & $5^{\circ} 14^{\prime} 25.56^{\prime \prime} \mathrm{E}$ & Laboratory & $14 / 10 / 2018$ \\
\hline 24. & $7^{\circ} 15^{\prime} 46.63^{\prime \prime} \mathrm{N}$ & $5^{\circ} 14^{\prime} 25.84$ '’ $\mathrm{E}$ & Laboratory & $14 / 10 / 2018$ \\
\hline 25. & $7^{\circ} 15^{\prime} 47.76^{\prime \prime} \mathrm{N}$ & $5^{\circ} 14 ' 23.59^{\prime} ' \mathrm{E}$ & Office & $15 / 10 / 2018$ \\
\hline 26. & $7^{\circ} 15^{\prime} 46.28^{\prime \prime} \mathrm{N}$ & $5^{\circ} 14^{\prime} 26.29^{\prime \prime} \mathrm{E}$ & Office & $15 / 10 / 2018$ \\
\hline 27. & $7^{\circ} 15^{\prime} 46.36^{\prime \prime} \mathrm{N}$ & $5^{\circ} 14 ' 24.71$ '’ $\mathrm{E}$ & Office & $15 / 10 / 2018$ \\
\hline 28. & $7^{\circ} 15^{\prime} 46.40^{\prime \prime} \mathrm{N}$ & $5^{\circ} 14 ' 24.46^{\prime \prime} \mathrm{E}$ & Office & $15 / 10 / 2018$ \\
\hline 29. & $7^{\circ} 15^{\prime} 48.02^{\prime \prime} \mathrm{N}$ & $5^{\circ} 14 ' 24.48^{\prime \prime} \mathrm{E}$ & Office & $16 / 10 / 2018$ \\
\hline 30. & $7^{\circ} 15^{\prime} 47.58^{\prime \prime} \mathrm{N}$ & $5^{\circ} 14^{\prime} 23.77^{\prime}{ }^{\prime} \mathrm{E}$ & Classroom & $16 / 10 / 2018$ \\
\hline 31. & $7^{\circ} 15^{\prime} 47.57^{\prime \prime} \mathrm{N}$ & $5^{\circ} 14 ' 23.71$ '’ $\mathrm{E}$ & Classroom & $16 / 10 / 2018$ \\
\hline 32. & $7^{\circ} 16^{\prime} 10.96{ }^{\prime \prime} \mathrm{N}$ & $5^{\circ} 13^{\prime} 37.98^{\prime \prime} \mathrm{E}$ & Classroom & $16 / 10 / 2018$ \\
\hline
\end{tabular}

\subsection{Parameter Measurements}

The present measurements were done at 32 indoor locations (Classrooms (3), residential homes (17), laboratories (6), offices (5), and shop (1) - Table 1) in Akure. The current assessment of formaldehyde (HCHO), Total Volatile Organic Compounds (TVOC), $\mathrm{PM}_{1.0}, \mathrm{PM}_{2.5}$, and $\mathrm{PM}_{10}$ was performed using a multifunction air detector (Model: WP6910 made-in-China: Detector Description (Table 2). Presently, there are no national-controlling ambient air quality monitoring sites in Akure city, this informed the use of this detector. The mini GPS used for the coordinates of the sites is made-in-China (Model: GPS-006E). The manufacturers' specifications and procedures were strictly followed. During the indoor assessments, the detector device was placed in the center of the room at the height approximately $1.1 \mathrm{~m}$ above the ground for $1 \mathrm{~h}$. Before the measurements, all the air conditions, fans, other ventilators were switched off, and all windows 
Table 2. The Detector Description

\begin{tabular}{lllll}
\hline $\begin{array}{l}\text { Display } \\
\text { Mode }\end{array}$ & $\begin{array}{l}\text { Power } \\
\text { Supply }\end{array}$ & $\begin{array}{l}\text { Pollutant } \\
\text { Range }\end{array}$ & Detection Technology & Concentration \\
\hline LED & $1200 \mathrm{mAh} *$ & HCHO & Electrochemistry Sensing Technology & $0-1.999 \mathrm{mg} / \mathrm{m}^{3}$ \\
& & TVOC & Electrochemistry Sensing Technology & $0 \sim 9.999 \mathrm{mg} / \mathrm{m}^{3}$ \\
& & PM $_{1.0}$ & Adopting Laser Scattering Theory & $0 \sim 999 \mu \mathrm{g} / \mathrm{m}^{3}$ \\
& & $\mathrm{PM}_{2.5}$ & Adopting Laser Scattering Theory & $0 \sim 999 \mu \mathrm{g} / \mathrm{m}^{3}$ \\
& & $\mathrm{PM}_{10}$ & Adopting Laser Scattering Theory & $0 \sim 999 \mu \mathrm{gg} / \mathrm{m}^{3}$ \\
\hline
\end{tabular}

* Rechargeable lithium battery, Input: $5.0 \mathrm{~V} / 300 \mathrm{~mA}$

and doors were shut during the measurement periods. Assessments were carried out in the living rooms because they are the central rooms where members of the families spend time together (Meciarová et al., 2017). Also, the $\mathrm{PM}_{2.5} / \mathrm{PM}_{10}$ was determined. The assessment was performed in seven days $\left(10^{\text {th }}-16^{\text {th }}\right.$ October 2018). The weather report on rainfall, relative humidity $(\mathrm{RH})$, temperature, precipitate, wind speed, and direction was obtained at the Federal University of Technology, Akure, Ondo State.

\subsection{Statistical Analysis}

Results from experimental measurement were statistically evaluated using the Minitab 16 (Minilab Ltd. UK) and Microsoft Office Excel 2007 (Microsoft Corporation Technology Company, Washington, US) software. The wind rose, concentrations of HCHO, TVOC, $\mathrm{PM}_{1}$, $\mathrm{PM}_{2.5}$, and $\mathrm{PM}_{10}$ were obtained using the Microsoft Excel, while basic description, matrix and box plots and dendogram were obtained by Minitab tools.

\section{Results and Discussion}

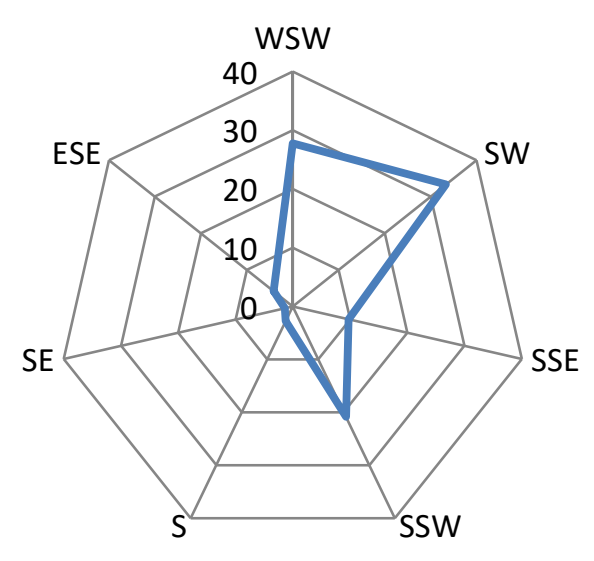

Fig 2. Wind Direction for the month of October, 2018 
Table 3. Summary of the meteorological data

\begin{tabular}{lllll}
\hline Statistics & Temperature & Wind Speed & Humidity & Precipitate \\
\hline Range & & & & \\
Mean & $22.0-33.0\left({ }^{\circ} \mathrm{C}\right)$ & $1.0-9.0(\mathrm{~m} / \mathrm{s})$ & $46.0-99.0(\%)$ & $0.0-36(\mathrm{~mm})$ \\
Std Error & 25.88 & 5.03 & 83.94 & 1.75 \\
Std Deviation & 0.39 & 0.18 & 1.92 & 0.66 \\
Coef Variation (\%) & 3.34 & 1.53 & 16.25 & 5.59 \\
Skewness & 12.91 & 30.41 & 19.36 & 319.59 \\
Kurtosis & 0.53 & -0.12 & -0.83 & 5.41 \\
\hline
\end{tabular}

The mean meteorological data for the month of October 2018 were as follows: Temperature $\left(25.88{ }^{\circ} \mathrm{C}\right)$, wind $(5.03 \mathrm{~m} / \mathrm{s})$, humidity $(83.94 \%)$, precipitate $(1.75 \mathrm{~mm})$ (Table 3$)$, and the wind direction for the month was predominantly from WSW, SW, SSE, and SSW (Fig 2). The results obtained in Turkey for precipitate, wind speed, and RH compared with our results (Lokman et al., 2008). There were no significant differences in the data during the seven day assessment as noted by the low percentage in the correlation of variations. The correlation coefficient in Table 4 confirmed the strong positive correlation of $\mathrm{PM}_{1}, \mathrm{PM}_{2.5}$, and $\mathrm{PM}_{10}$ concentrations with the prevailing temperature $(r=0.889,0.732$, and 0.796 respectively), while there were weak positive

Table 4. Correlation Coefficient of the pollutants and meteorological parameters

\begin{tabular}{llllllllll}
\hline & HCHO & TVOC & PM $_{1.0}$ & PM $_{2.5}$ & PM $_{10}$ & Temp & Wind & Hum Precip \\
\hline HCHO & 1 & & & & & & & & \\
TVOC & 0.000 & 1 & & & & & & & \\
PM $_{1.0}$ & $\mathbf{0 . 6 4 9}$ & $\mathbf{0 . 7 2 2}$ & 1 & & & & & & \\
PM $_{2.5}$ & $\mathbf{0 . 7 1 0}$ & $\mathbf{0 . 5 8 7}$ & 0.000 & 1 & & & & & \\
PM $_{10}$ & $\mathbf{0 . 9 3 1}$ & $\mathbf{0 . 9 2 8}$ & 0.000 & 0.000 & 1 & & & & \\
Temp & $\mathbf{0 . 5 0 3}$ & 0.402 & $\mathbf{0 . 8 8 9}$ & $\mathbf{0 . 7 3 2}$ & $\mathbf{0 . 7 9 6}$ & 1 & & & \\
Wind & $\mathbf{0 . 9 0 0}$ & $\mathbf{0 . 7 8 1}$ & $\mathbf{0 . 6 8 2}$ & 0.423 & $\mathbf{0 . 5 7 8}$ & 0.000 & 1 & & \\
Hum & $\mathbf{0 . 9 9 7}$ & $\mathbf{0 . 8 1 8}$ & $\mathbf{0 . 8 7 6}$ & $\mathbf{0 . 8 5 6}$ & $\mathbf{0 . 8 7 6}$ & 0.000 & 0.001 & 1 & \\
Precip & 0.000 & 0.000 & 0.226 & 0.204 & 0.229 & $\mathbf{0 . 8 9 7}$ & $\mathbf{0 . 9 1 1}$ & 0.382 & 1 \\
\hline
\end{tabular}

correlations between temperature and $\mathrm{HCHO}$ and TVOC $(\mathrm{r}=0.503$ and 0.402 respectively). This means that $\mathrm{HCHO}$, TVOC, and PM concentrations in indoors were intensified with temperature. Temperature has been known to influence pollutants' emissions (HCHO and TVOC) from building materials together with air velocity and humidity (Wolkoff, 1998). Similar trends were also observed for wind and humidity, only precipitate did not have any significant relationship with the pollutants undertaken in this study. It can be deduced that the emitted substances were temperature, wind speed, and humidity dependent. Wind speed is a principal factor in the control of air pollution levels Grivas and Chaloulakou, 2006), wind direction plays a major role in the transport, dilution, and re-suspension of $\mathrm{PM}_{10}$ (Harrison et al., 1997; Shahraiyni and Sodoudi, 2016), and temperature is considered as one of the strongest predictors of $\mathrm{PM}_{10}$ concentration (Papanastasiou et al., 2007). 


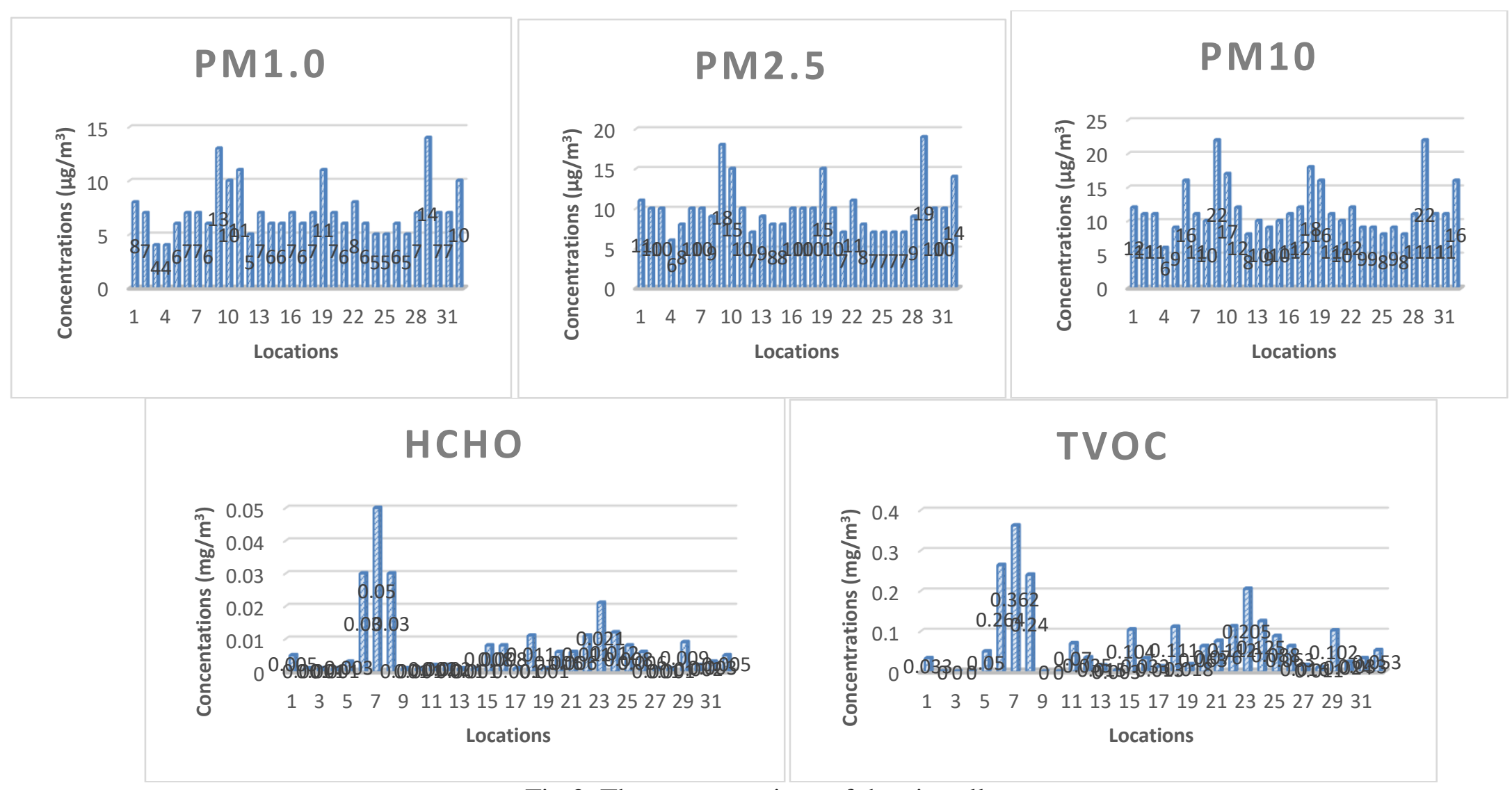

Fig 3. The concentrations of the air pollutants 
Table 5. Basic Statistical Description of the Pollutants

\begin{tabular}{lcccccc}
\hline Statistics & HCHO & TVOC & $\mathrm{PM}_{1.0}$ & $\mathrm{PM}_{2.5}$ & $\mathrm{PM}_{10}$ & $\mathrm{PM}_{2.5} / \mathrm{PM}_{10}$ \\
& & & & & & \\
\hline Range & $0.001-0.050$ & $0.001-0.362$ & $4.000-14.000$ & $6.000-19.000$ & $6.000-22.000$ & $0.560-0.940$ \\
Mean & .008 & 00.072 & 7.242 & 10.030 & 11.818 & 0.851 \\
Std Error & 0.002 & 0.015 & 0.411 & 0.536 & 0.661 & 0.015 \\
Std Deviation & 0.011 & 0.085 & 2.359 & 3.077 & 3.795 & 0.086 \\
Coef Variation (\%) & 139.12 & 119.56 & 32.57 & 30.68 & 32.11 & 10.12 \\
Skewness & 2.61 & 1.92 & 1.32 & 1.45 & 1.34 & -1.99 \\
Kurtosis & 7.47 & 3.72 & 1.62 & 2.09 & 1.56 & 4.05 \\
TP & $0.01-0.5$ & - & - & $0.17-0.54$ & $0.12-0.44$ & - \\
\hline
\end{tabular}

$\mathrm{TP}$ - Toxicity Potential 
Table 6. Comparisons with other studies

\begin{tabular}{|c|c|c|c|c|c|c|}
\hline References & $\mathrm{HCHO}$ & TVOC & $\mathrm{PM}_{1.0}$ & $\mathrm{PM}_{2.5}$ & $\mathrm{PM}_{10}$ & $\mathrm{PM}_{2.5} / \mathrm{PM}_{10}$ \\
\hline Munir (2017) & - & - & - & - & - & $0.33-0.88$ \\
\hline Filonchyk et al., & - & - & - & $25-28$ & $50-70$ & $0.50-0.90$ \\
\hline Ho et al. (2003) & - & - & - & $42.37-57.38$ & $73.11-83.52$ & $0.53-0.78$ \\
\hline Hassanvand et al. (201 & 14) & - & $10.70-11.00$ & $16.90-19.00$ & $39.70-53.70$ & - \\
\hline Lim et al. (2005). & - & - & $5.60-13.10$ & $12.80-31.10$ & $27.50-93.90$ & - \\
\hline Cai et al. (2015) & $0.80-3.90$ & $42-152$ & $255.00-376.00$ & $261.00-383.0$ & $325.00-439.0$ & - \\
\hline Xu et al. (2017a) & - & - & - & $7.00-356.00$ & $15.00-415.00$ & $0.20-0.90$ \\
\hline $\begin{array}{l}\text { Evagelopoulous et al. } \\
\text { (2006) }\end{array}$ & - & - & - & 19.00 & 47.00 & $0.42-0.44$ \\
\hline Wang et al. (2014) & - & - & 99.00 & 175.00 & $0.70-0.80$ & - \\
\hline $\begin{array}{l}\text { Me ciarová et al. } \\
\text { (2017) }\end{array}$ & $13.50-1712$ & & - & $13.10-44.10$ & 87.80 & - \\
\hline Kim et al. (2014) & $1.115-1.703$ & & $2.82-11.30$ & $2.86-11.40$ & $3.09-11.90$ & - \\
\hline Hadei et al. (2018) & 17.90 & & & & & \\
\hline Huang et al. (2015) & - & & - & 100 & 157 & 0.64 \\
\hline Chen et al. (2014) & - & & - & 51 & 76 & $0.57-0.71$ \\
\hline Zhou et al. (2015) & - & & - & 92 & 119 & $0.53-0.86$ \\
\hline Our results & $0.001-0.050$ & $0.001-0.36$ & $4.00-14.00$ & $6.00-19.00$ & $6.00-22.00$ & $0.56-0.94$ \\
\hline
\end{tabular}


Table 7. AQI index scoring system

\begin{tabular}{|c|c|c|c|c|}
\hline IQE & Good & Average & Poor & $\mathrm{Bad}$ \\
\hline Humidity & $40-50 \%$ & $50-60 \%$ & $60-70 \%$ & $70>\mathrm{H}>40 \%$ \\
\hline Temperature & $20-24^{\circ} \mathrm{C}$ & $16-20^{\circ} \mathrm{C}$ & $24-26^{\circ} \mathrm{C}$ & $26>\mathrm{T}>16^{\circ} \mathrm{C}$ \\
\hline $\mathrm{PM}_{2.5}$ & $0-10 \mu \mathrm{g} / \mathrm{m} 3$ & $10-15 \mu \mathrm{g} / \mathrm{m} 3$ & $15-35 \mu \mathrm{g} / \mathrm{m} 3$ & $>35 \mu \mathrm{g} / \mathrm{m} 3$ \\
\hline $\mathrm{PM}_{10}$ & $0-50 \mu \mathrm{g} / \mathrm{m} 3$ & $50-80 \mu \mathrm{g} / \mathrm{m} 3$ & $80-150 \mu \mathrm{g} / \mathrm{m} 3$ & $>150 \mu \mathrm{g} / \mathrm{m} 3$ \\
\hline \multicolumn{5}{|l|}{$\mathrm{PM}_{1.0}$} \\
\hline TVOC & 0-200ppb & 200-350ppb & 350-500ppb & $>500 \mathrm{ppb}$ \\
\hline $\mathrm{CO}_{2}$ & $350-500 \mathrm{ppm}$ & 500-1000ppm & $1000-5000 \mathrm{ppm}$ & $>5000 \mathrm{ppm}$ \\
\hline $\mathrm{CO}$ & $0-3 p p m$ & 3-8ppm & 8-10ppm & $>10$ ppm \\
\hline Indoor air quality & $0-10 p p m$ & $10-25 \mathrm{ppm}$ & $25-50 \mathrm{ppm}$ & $>50$ ppm \\
\hline Illuminance & $300-5001 u x$ & 200-300lux & 100-200lux & $<100$ lux \\
\hline Sound levels & $0-40 \mathrm{~dB}$ & $40-70 \mathrm{~dB}$ & $70-80 \mathrm{~dB}$ & $>80 \mathrm{~dB}$ \\
\hline Scoring impact & 0 & 0.2 & 0.5 & 1.0 \\
\hline
\end{tabular}

Source: Tiele et al. (2018). 
Figure 3 showed the results of the assessments determined in this study. Also, Table 5 depicted the summary of results for the pollutants. The ranges of the parameters were: 0.001-0.050, 0.001$0.362,4.000-14.000,6.000-19.000,6.000-22.000$, and 0.560-0.940, while the mean values were: 0.008, 0.072, 7.242, 10.030, 11.818, and 0.851 (HCHO, TVOC, PM $1.0, \mathrm{PM}_{2.5}, \mathrm{PM}_{10}$, and $\mathrm{PM}_{2.5} / \mathrm{PM}_{10}$ ) respectively. The only place where the highest value of $0.05 \mathrm{mg} / \mathrm{m}^{3}$ was recorded for formaldehyde happened to be in a residential home and this could be a result of the wallpaper and the new sets of furniture in the living room. It is gratifying to note that the value was below the thresholds of eye irritation $\left(0.1 \mathrm{mg} / \mathrm{m}^{3}\right)$, biting sensation in nose $\left(0.5 \mathrm{mg} / \mathrm{m}^{3}\right)$, danger to life $\left(37.5 \mathrm{mg} / \mathrm{m}^{3}\right)$, and even death $\left(125 \mathrm{mg} / \mathrm{m}^{3}\right)$ (Commission of the European Communities (1990). The means $\left(0.072 \mathrm{mg} / \mathrm{m}^{3}\right)$ and standard deviations $(0.085)$ of TVOC showed significant differences between our indoor results with those of Lee et al. 2018 (Korea - 230.7 $\pm 1.7 \mu \mathrm{g} / \mathrm{m}^{3}$ ); Me ciarová et al. 2017 (Slovak - 28-2393 $\mu \mathrm{g} / \mathrm{m}^{3}$ ), Wang et al. 2008 (Taiwan $-1.960 \mu \mathrm{g} / \mathrm{m}^{3}$ ), and Park et al. 2010 (Korea - 120 to $328 \mu \mathrm{g} / \mathrm{m} 3$ ). The reason for the differences could be deduced to the old age of our study sites. The indoor mean values of $\mathrm{PM}_{10}, \mathrm{PM}_{2.5}$, and $\mathrm{PM}_{1.0}$ in our study were lower during the weekdays compared to the weekends, the differences were due to the increase in the residents' activities during the weekend due to the holidays. These types of results have been experienced by Goyal and Khare (2010) although they recorded higher concentrations than our results.

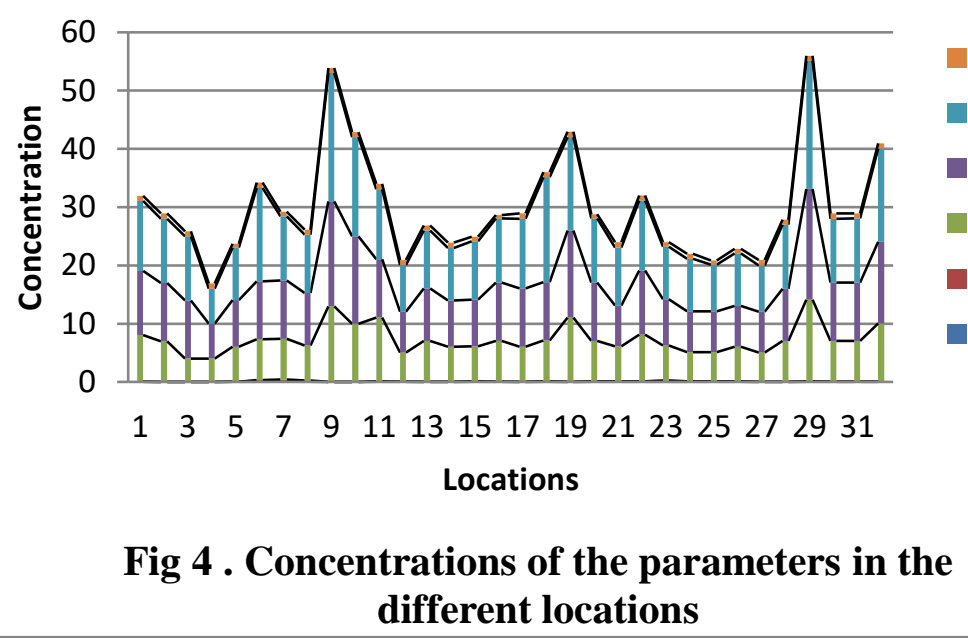

The mean concentrations of the particulate matter were: $\mathrm{PM}_{10}\left(11.818 \mu \mathrm{g} / \mathrm{m}^{3}\right), \mathrm{PM}_{2.5}(10.030$ $\left.\mu \mathrm{g} / \mathrm{m}^{3}\right)$, and $\mathrm{PM}_{1.0}\left(7.242 \mu \mathrm{g} / \mathrm{m}^{3}\right)$. Table 6 showed the comparison of our results with the previous studies. The $\mathrm{PM}_{10}$ results were lower than those in subway offices $\left(27.5\right.$ to $\left.267.9 \mu \mathrm{g} / \mathrm{m}^{3}\right)$ obtained by Lim et al. (2005). Hassanvand et al. (2014) who carried out the indoor/outdoor relationships of $\mathrm{PM}_{10}, \mathrm{PM}_{2.5}$, and $\mathrm{PM}_{1}$ in a retirement home and dormitory obtained for $\mathrm{PM}_{10}\left(7.5-240 \mathrm{mg} / \mathrm{m}^{3}\right)$, $\mathrm{PM}_{2.5}\left(4.4-72.3 \mathrm{mg} / \mathrm{m}^{3}\right)$, and $\mathrm{PM}_{1}\left(3.1-42.0 \mathrm{mg} / \mathrm{m}^{3}\right)$. The summary of these results showed that there were relationships obtained in this study. The Nigerian PM standards are the same as WHO limits $\left(50\right.$ and $25 \mathrm{mg} / \mathrm{m}^{3}$ ) daily average $\mathrm{PM}_{10}$ and $\mathrm{PM}_{2.5}$ concentrations, respectively. Presently, no standard limit is available for $\mathrm{PM}_{1}$. It could be deduced from our results that they below the WHO limits. The reason could be due to the low rainfall recorded during the seven day monitoring. The $\mathrm{PM}_{2.5} / \mathrm{PM}_{10}$ values in this study on the average ranged between 0.50 and 0.90 with an average of 0.851 (Fig 4). Ho et al. (2003) at three monitoring sites in Hong Kong found 
that the mean $\mathrm{PM}_{2.5} / \mathrm{PM}_{10}$ ratios were higher in Poly U (0.61) and KT (0.78) than in HT (0.53). In addition, Filonchyk et al. (2016) showed lower ratios of 0.29-0.51. Using the previous studies results it could be observed that the PM indicators are dust storms depicted by high $\mathrm{PM}_{10}$ contents and relatively low contents of $\mathrm{PM}_{2.5}$ due to the invasion of large particles (Zhang et al., 1998). It should be noted that the $\mathrm{PM}_{2.5} / \mathrm{PM}_{10}$ ratio may be used as a key measurement to determine the sources of dust. In line with our results, Xu et al. (2017b), obtained above 0.7 of $\mathrm{PM}_{2.5} / \mathrm{PM}_{10}$ ratios at 19 cities in China, while below 0.5 was recorded at the other cities they studied. The low differences in PM concentrations and the high ratios of $\mathrm{PM}_{2.5} / \mathrm{PM}_{10}$ obtained in this study showed generally modest PM concentrations, and the possible emission sources include unpaved road and agriculture.

Table 8. Principal Component Analysis of the indoor pollutants

\begin{tabular}{lccccc}
\hline Variable & PC1 & PC2 & PC3 & PC4 & PC5 \\
& & & & & \\
\hline HCHO & -0.102 & $\mathbf{- 0 . 6 9 8}$ & -0.025 & -0.332 & $\mathbf{- 0 . 6 2 6}$ \\
TVOC & -0.106 & -0.698 & 0.093 & $\mathbf{- 0 . 6 9 8}$ & $\mathbf{0 . 6 4 4}$ \\
PM $_{1}$ & $\mathbf{0 . 5 6 8}$ & -0.062 & $\mathbf{0 . 7 4 0}$ & 0.289 & -0.206 \\
PM $_{2.5}$ & $\mathbf{0 . 5 8 3}$ & 0.060 & -0.070 & $\mathbf{- 0 . 7 2 4}$ & 0.358 \\
PM $_{10}$ & $\mathbf{0 . 5 6 2}$ & -0.134 & $\mathbf{- 0 . 6 6 2}$ & 0.451 & -1.555 \\
Eigenvalue & 2.803 & 1.962 & 0.147 & 0.073 & 0.015 \\
Proportion & 0.561 & 0.392 & 0.029 & 0.015 & 0.003 \\
Cumulative & 56.10 & 95.53 & 98.20 & 99.70 & 100.0 \\
\hline
\end{tabular}

The principal component analysis (PCA) of the data collected (Minitab 16, Minilab Ltd. UK) showed that the first two principal components accounted for $56 \%$ of the variability in the system. Component (PC1) was predominantly associated with $\mathrm{PM}_{1}, \mathrm{PM}_{2.5}$, and $\mathrm{PM}_{10}$ contents, PC2 was associated mainly with $\mathrm{HCHO}$, and PC5 was associated with TVOC. The implication of this was that there were some mutual correlations. The mutual correlations shown between all principal components are shown in Table 8. Table 4 confirmed the correlations that existed within the parameters. The Pearson correlation factor that existed were HCHO: $\mathrm{PM}_{1}(\mathrm{r}=0.63)$, HCHO: $\mathrm{PM}_{2.5}$ (r=0.69), HCHO: $\mathrm{PM}_{10}$ (r=0.93) and TVOC: $\mathrm{PM}_{1}(\mathrm{r}=0.69)$, TVOC: $\mathrm{PM}_{2.5}(\mathrm{r}=0.57)$, and TVOC; $\mathrm{PM}_{10}(\mathrm{r}=0.93)$. All were strongly correlated. There were strong correlations between the different PM measurements and also between the different aromatic components. TVOC also shows high correlation with many of the individual components, as would be expected this suggested the pollutant sources come from the same source. 


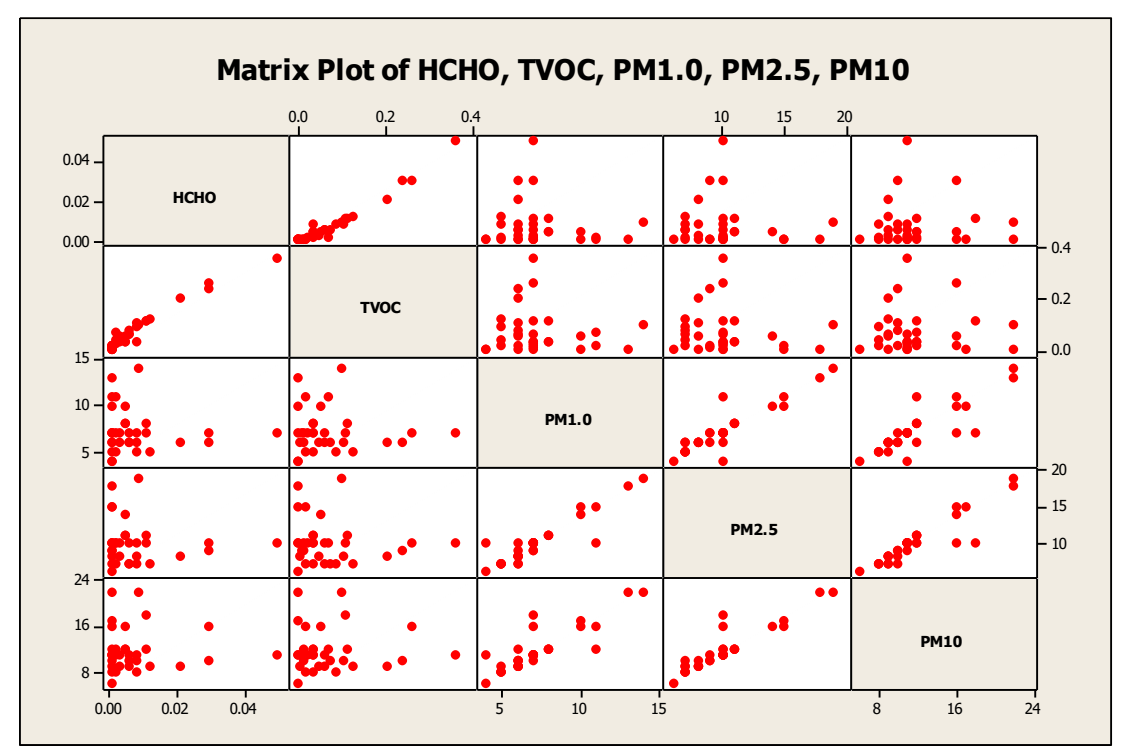

Fig 5. Matrix plot of the pollutants

Matrix plot was also plotted to evaluate the relationship between the measured PM, HCHO, and TVOC from the closed rooms. Matrix Scatterplot has variables that are written in a diagonal line from top left to bottom right (Fig 5). The HCHO, TVOC, $\mathrm{PM}_{1.0}, \mathrm{PM}_{2.5}$, and $\mathrm{PM}_{10}$ known as the variables were plotted against each other. The boxes on the upper right-hand side of the whole scatterplot were mirror images of the plots on the lower left hand. In the graph, it was shown that there were strong correlations between HCHO, TVOC, $\mathrm{PM}_{1.0}, \mathrm{PM}_{2.5}$, and $\mathrm{PM}_{10}$.

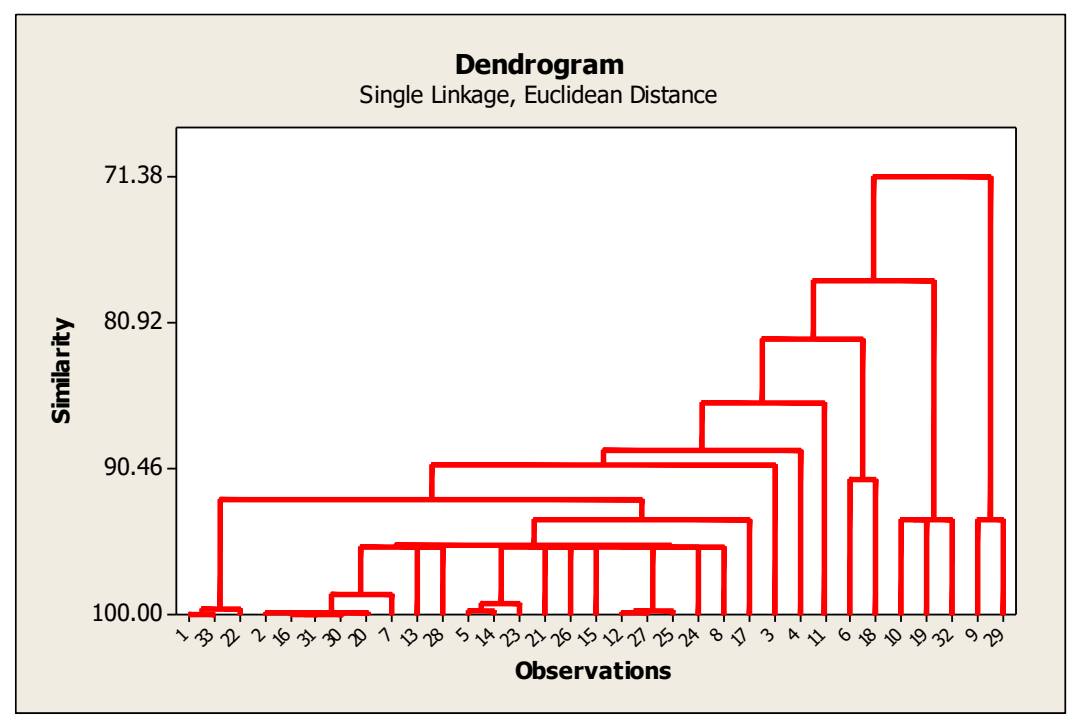

Fig 6. Dendogram of the results 
The dendogram plot in Fig 6 showed that the results obtained in the study were highly comparable to the patterns derived by the PCA. They depicted the correlations between the pollutants. The results of multivariate analysis confirmed the different associations among the evaluated parameters, this could be due to PMs formed by secondary aerosol. The $\mathrm{PM}_{2.5}$ and $\mathrm{PM}_{10}$ skewed to the right, which means they are nonsymmetrical (Fig 5). The reason for the skewing to the right was that there were variations in the values of PM recorded in the study. The boxplot is a visual display that presents five different statistical tools in a study - the minimum, the lower quartile, the median, the upper quartile, and the maximum. It is an indicator of centrality, symmetry, spread and tail length of the population and sample (Abulude et al., 2018a).

Table 7 is the IEQ index scoring system developed by Tiele et al. (2018) the aim was to design a scoring point that can rate the parameter readings of indoor pollutants. In this study, the scoring index was used to score the pollutants assessed in some parts of Akure. The results of the meteorological parameters and the pollutants can be rated as between average and good. Again, the AQI calculator (Airnow, Accessed 2018) was used (concentration to AQI) to determine the air category of $\mathrm{PM}_{10}$ and $\mathrm{PM}_{2.5}$. The $\mathrm{PM}_{10}$ results (AQI) were between $6(\min )$ and $18(\max )$ denoting 'Good', the sensitive groups at risk are people with respiratory disease, while $\mathrm{PM}_{2.5}$ had $\mathrm{AQI}=25(\mathrm{~min})$ and $55(\mathrm{max})$ denoting 'Good and Moderate' respectively, the sensitive groups at risk are people with respiratory or heart disease, the elderly and children.

The TP range was computed for $\mathrm{HCHO}, \mathrm{PM}_{2.5}$, and $\mathrm{PM}_{10}$ using Nigeria's 24-h standard averaging period of FMEnv and ASHRAE Standard Ventilation for Acceptable IAQ (Tables 5). The TP of TVOC and $\mathrm{PM}_{1}$ were not computed because their FMEnv and ASHRAE standards were provided. The TP were 0.01-0.5 (HCHO), 0.17-0.54 ( $\left.\mathrm{PM}_{2.5}\right)$, and 0.12-0.44 ( $\left.\mathrm{PM}_{10}\right)$. In a TSP study conducted by Sonibare et al. (2005) at an Enamelware Manufacturing Industry, between 0.33 and 7.72 were recorded for the TP. The high concentration obtained in their study could be as a result of the activities (spraying, pickling process, milling etc) that took place when the research was held, but in our study, it was only little vehicular activity that took place.

\section{Conclusion}

The assessment of pollutants indoor was carried out within seven days in Akure using a multifunctional air detector. The results revealed that Formaldehyde (HCHO) was minimal in all the locations which could have been due to the old age of the buildings and materials therein. In comparison with standard limits its results were far below the limits. TVOC was also detected at very low concentrations. There were significant differences when compared with indoors in Korea. The PM at diameters 1, 2.5, and 10 was low compared to the $24 \mathrm{hr}$ indoor limit recommended by WHO. The PM ratios were below unity. The coefficient of correlation and matrix plots depicted strong correlations between PM, HCHO, and TVOC. The report showed that there were significant effects of weather on the pollutants, especially temperature. The PCA revealed associations in the pollutants. The results of the meteorological parameters and the pollutants can be rated as 'average' and 'good'. The sensitive groups at risk are people with respiratory or heart disease, the elderly and children. The TP report showed that the potential of the indoor inhabitants is low, but the probability of human health effects exists due to the activities within and outside the different locations. Finally, it is recommended that constant monitoring of the locations assessed should be enforced. 


\section{Conflict of interest statement}

The authors certify that they have no conflict of interest concerning the subject matter or materials discussed in the manuscript.

\section{Acknowledgments}

The authors are grateful to Dr. Cynthia Onyefulu, an Associate Professor and the Vice-Dean in the Faculty of Education and Liberal Studies at the University of Technology, Jamaica for the provision of funds for the purchase of the multifunction air detector and landlords who permitted us to use their living rooms.

\section{References}

Abulude F.O., Ndamitso M.M., Abdulkadir A. (2018a). Rainfall water quality assessment in atmospheric deposition of an urban area: A case study of Akure in Nigeria. Anthropogenic Pollution Journal. 2 (2), 2018: 1-9.

Abulude F.O., Ndamitso M.M., Abdulkadir A. (2018b).Environmental Situation of an Agricultural Area in Akure, Nigeria, Based on Physico-Chemical Properties of Rainwater. Pollution, 4(2): 317-325.

Afolabi O T, Awopeju O F, Aluko O O, Deji S A, Olaniyan B B, Agbakwuru L C, Oyedele O O, Oni K R, Ojo B O. (2016). Awareness of indoor air pollution and the prevalence of respiratory symptoms in an urban community in South West Nigeria. Niger J Health Sci2016;16:33-8.

Airnow.gov (2018). Air calculator. Air Quality Index. USEPA. https://www.airnow.gov/index.cfm?action=airnow.calculator. Accessed $21^{\text {st }}$ November, 2018.

Akpofure Rim-Rukeh (2015). An Assessment of Indoor Air Quality in Selected Households in Squatter Settlements Warri, Nigeria, Advances in Life Sciences, Vol. 5 (1) 1-11. doi: 10.5923/j.als.20150501.01.

Ayodele C.O., Fakinle B.S., Jimoda L.A., and Sonibare J.A (2016). Investigation on the ambient air quality in a hospital environment. Cogent Environmental Science, 2: 1215281.

Cai W., Yoshino H., Zhu S., Yanagi U., Kagi N., and Hasegawa K (2015). Investigation of Microclimate and Air Pollution in the Classrooms of a Primary School in Wuhan. Procedia Engineering 121, 415 - 422 .

Chen, J., Xin, J., An, J., Wang, Y., Liu, Z., Chao, N. and Meng, Z. (2014). Observation of aerosol optical properties and particulate pollution at background station in the Pearl River Delta region. Atmos. Res. 143: 216-227.

Chen Y. Sung F., Chen M., Mao I., and Lu C. (2016). Indoor Air Quality in the Metro System in North Taiwan. Int. J. Environ. Res. Public Health, 13, 1200; doi:10.3390/ijerph13121200 
Commission of the European Communities (1990). Indoor air quality and its impact on man. Environment and quality of life. Indoor air pollution by formaldehyde in European countries. Report No. 7. Pp 1-2.

Evagelopoulous V., Zoras S., Triantafyllou A.G., Abanis T.A (2006). PM10-PM2.5 Time Series and Fractal Analysis. Global NEST Journal, Vol 8, No 3, pp 234-240.

Ezezue AM, Diogu JO (2017) Investigation of Indoor Air Quality of Residential Buildings in Enugu, Nigeria. J ArchitEng Tech 6: 206. doi: 10.4172/2168-9717.1000206.

Fanger A (2006). What is IAQ? Indoor Air. 2;16(5):328-34.

FilonchykM., Yan H., Yang S., and Hurynovich V. (2016). A study of $\mathrm{PM}_{2.5}$ and $\mathrm{PM}_{10}$ concentrations in the atmosphere of large cities in Gansu Province, China, in summer period. $J$. Earth Syst. Sci., DOI 10.1007/s12040-016-0722-x, 125, No. 6, August 2016, pp. 1175-1187.

Goyal R and Khare $\mathrm{M}$ (2010). Indoor air quality modeling for $\mathrm{PM}_{10}, \mathrm{PM}_{2.5}$, and $\mathrm{PM}_{1.0}$ in naturally ventilated classrooms of an urban Indian school building. Environ Monit Assess DOI 10.1007/s10661-010-1600-7.

Grivas, G.; Chaloulakou, A. (2006). Artificial neural network models for prediction of PM $_{10}$ hourly concentrations, in the Greater Area of Athens, Greece. Atmos. Environ., 40, 1216-1229.

Hadei M., Hopke P.K., Rafiee M., Rastkari N., Yarahmadi M., Kermani M., and Shahsavani A (2018). Indoor and outdoor concentrations of BTEX and formaldehyde in Tehran, Iran: effects of building characteristics of health risk assessment. Environmental Science and Pollution Research. 25:27423-27437.

Harrison, R.M.; Deacon, A.R.; Jones, M.R.; Appleby, R.S. (1997). Sources and processes affecting concentrations of $\mathrm{PM}_{10}$ and $\mathrm{PM}_{2.5}$ particulate matter in Birmingham (U.K.). Atmos. Environ., 31, 4103-4117.

Hassanvand M.S., Naddafi K., Faridi S., Arhami M., Nabizadeh R., Sowlat M. H., Pourpak Z., Rastkari N., Momeniha F., Kashani H., Gholampour A., Nazmara S., Alimohammadi M., Goudarzi G., and Yunesian M. (2014). Indoor/outdoor relationships of $\mathrm{PM}_{10}, \mathrm{PM}_{2.5}$, and $\mathrm{PM}_{1}$ mass concentrations and their water-soluble ions in a retirement home and a school dormitory. Atmospheric Environment. 82 (2014) 375-382.

Ho K.F., Lee S.C., Chan C.K., Yu J.C., Chow J.C., and YaO X.H. (2003). Characterization of chemical species in $\mathrm{PM}_{2.5}$ andPM 10 aerosols in Hong Kong. Atmospheric Environment 37, 3139.

Huang, W., Long, E., Wang, J., Huang, R. and Ma, L. (2015). Characterizing spatial distribution and temporal variation of PM10 and PM2.5 mass concentrations in an urban area of southwest China. Atmos. Pollut. Res. 6: 842-848. 
Jiao, W., Hagler, G.S.W., Williams, R.W., Sharpe, R.N., Weinstock, L., Rice, J., 2015. Field assessment of the village green project: an autonomous community air quality monitoring system. Environ. Sci. Technol. 49 (10), 6085-6092.

Lee K, Choi J-H, Lee S, Park H-J, Oh Y-J, Kim G-B, et al.(2018). Indoor levels of volatile organic compounds and formaldehyde from emission sources at elderly care centers in Korea. PLoSONE 13(6):e0197495. https://doi.org/10.1371/journal.pone.0197495.

Li, M., Shao, M., Li, L. Y., Lu, S. H., Chen, W. T., andWang, C. (2014). Quantifying the ambient formaldehyde sources utilizing tracers, Chin. Chem. Lett., 25, 14891491,doi:10.1016/j.cclet.2014.07.001.

Lim H.J., Kim H.W., and Lee S.C. (2005). Concentrations of Particulate Matters (TSP, Pm10, Pm2.5, and Pm1) and Bioaerosol in the Above- and Under-Ground Subway Offices in Seoul. Proceedings: Indoor Air 2005: 1596-1600.

Lokman Hakan Tecer, Pinar Süren, Omar Alagha, Ferhat Karaca \& Gürdal Tuncel (2008) Effect of Meteorological Parameters on Fine and Coarse Particulate Matter Mass Concentration in a Coal-Mining Area in Zonguldak, Turkey, Journal of the Air \& Waste Management Association, 58:4, 543-552, DOI: 10.3155/1047-3289.58.4.543.

Ma Y., Diano Y., Zhang B., Wang W., Ren X., Yang D., Wang M., Shi X., and Zheng J (2016). Detection of formaldehyde emissions from an industrial zone in the Yangtze River Delta region of China using a proton transferreaction ion-drift chemical ionization mass spectrometer. Atmos. Meas. Tech., 9, 6101-6116.

Me`ciarová L., Vil`ceková S., Burdová E. K., and Kiselák J. (2017). Factors Effecting the Total Volatile Organic Compound (TVOC) Concentrations in Slovak Households. Int. J. Environ. Res. Public Health 2017, 14, 1443; doi:10.3390/ijerph14121443.

Munir S (2017). Analysing Temporal Trends in the Ratios of PM2.5/PM10 in the UK. Aerosol and Air Quality Research, 17: 34-48.

Papanastasiou, D.K.; Melas, D., Kioutsioukis, I. (2007). Development and assessment of neural network and multiple regression models in order to predict PM10 levels in a medium-sized Mediterranean city. Water Air Soil Pollut., 182, 325-334.

Park H, Oh Y, Lee H, Woo W, Sohn J. A study of indoor air quality of public facilities in Incheon city. J Korean Soc Environ Admin. 2010; 16(2):53-61.

Petry T., Vitale D., Joachim F.J., Smith B., Cruse L., Mascarenhas R., Schneider S., Singal M. (2014). Human health risk evaluation of selected VOC, SVOC and particulate emissions from scented candles. Regulatory Toxicology and Pharmacology 69 (2014) 55-7. 
Shahraiyni H.T and Sodoudi S. (2016). Statistical Modeling Approaches for PM10 Prediction in Urban Areas; A Review of 21st-Century Studies. Atmosphere, 7, 15; doi:10.3390/atmos7020015.

Shi L., Wang Y, Xu L., Liu Y., Jia Y., Yao D., and Li X. (2016). Evaluation of Purification Effect of Intelligent Air Purifier in the Pathology Department. J Med Surg Pathol., 1(4): 138. DOI: 10.4172/2472-4971.1000138.

Sonibare, J. A., Akeredolu, F. A., Osibanjo, O., and Latinwo, I. (2005). ED-XRF analysis of total suspended particulates from enamelware manufacturing industry. American Journal of Applied Science, 2, 573-578.

Tiele A., Esfahani S., and Covington J. (2018). Design and Development of a Low-Cost, Portable Monitoring Device for Indoor Environment Quality. Journal of Sensors. Volume 2018, https://doi.org/10.1155/2018/5353816.

U.S. Consumer Product Safety Commission (CPSC). 1995. Statement of Policy or Interpretation; Enforcement Policy for Art Materials. Consumer Product Safety Commission [FR Doc 95-3450 Filed 2-10-95 Available from: https://www.cpsc.gov/PageFiles/77793/027.txt.

Xu G., Jiao L., Zhang B., Zhao S., Yuan M., Gu Y., Liu J., and Tang X (2017a). Spatial and Temporal Variability of the PM2.5/PM10 Ratio in Wuhan, Central China. Aerosol and Air Quality Research, 17: 741-751.

Xu L, Batterman S., Hen F., Li J., Zhong X., Feng Y., Rao Q., and Chen F. (2017b). Spatiotemporal characteristics of PM2.5 and PM10 at urban and corresponding background sites in 23 cities in China. Sci Total Environ. 599-600: 2074-2084.

Van den Bossche, J., Peters, J., Verwaeren, J., Botteldooren, D., Theunis, J., De Baets, B.,2015. Mobile monitoring for mapping spatial variation in urban air quality: development and validation of a methodology based on an extensive dataset. Atmos. Environ. 105, 148-161.

Walgraeve C, Demeestere K, Dewulf J, VanHuffel K, Van Langenhove H. (2011). Diffusive sampling of 25 volatile organic compounds in indoor air: Uptake rate determination and application in Flemish homes for the elderly. Atmospheric Environment. 45 (32):5828-36.

Wang H., Tseng C., Hsieh T (2008). Developing an indoor air quality index system based on the health risk assessment. Indoor Air 2008, 17-22 August 2008, Copenhagen, Denmark - Paper ID: 749 .

Wang W., Maenhaut W., Yang W., Liu X., Bai Z., Zhang T., Claeys M., Cachier H., Dong S., and Wang Y. (2014). One-year aerosol characterization study for $\mathrm{PM}_{2.5}$ and $\mathrm{PM}_{10}$ in Beijing. Atmospheric Pollution Research, 5, 554-562.

Wolkoff P (1998) Impact of air velocity, temperature, humidity and air on longterm VOC emissions from building products. Atmospheric Environment. 32: 2659-2668. 
Zhang X Y, Arimoto R, Zhu G H, Chen T and Zhang G Y. (1998). Concentration, sizedistribution and deposition of mineral aerosol over Chinese desert regions; Tellus B. 50(4) 317330.

Zhou, Y., Cheng, S., Chen, D., Lang, J., Wang, G., Xu, T., Wang, X. and Yao, S. (2015). Temporal and spatial characteristics of ambient air quality in Beijing, China. Aerosol Air Qual. Res. 15: 1868-1880.

Zikova, N., Hopke, P.K., Ferro, A.R., 2017. Evaluation of new low-cost particle monitors for $\mathrm{PM}_{2.5}$ concentrations measurements. J. Aerosol Sci. 105, 24-34. 